\title{
"NOVEL METHODS FOR PHYSICAL MAPPING OF THE HUMAN GENOME APPLIED TO THE LONG ARM OF CHROMOSOME 5"
}

FINAL REPORT

$12 / 91$

JUN 221982

Michael McClelland

\author{
California Institute of Biological Research \\ 11099 North Torrey Pines Road \\ La Jolla \\ CA 92037
}

\section{DISCLAIMER}

This report was prepared as an account of work sponsored by an agency of the United States Governnent. Neither the United States Government nor any agency thereof, nor any of their employees, makes any warranty, express or implied, or assumes any legal liability or responsibility for the accuracy, completeness, or usefulness of any information, apparatus, product, or process disclosed, or represents that its use would not infringe privately owned rights. Reference herein to any specific commercial product, process, or service oy trade name, trademark, manufacturer, or otherwise does not necessarily constitute or imply its endorsement, recommendation, or favoring by the United States Government or any agency thereof. The views and opinions of authors expressed herein do not necessarily state or reflect those of the United States Government or any agency thereof.

\section{December 1991}

\section{PREPARED FOR THE DEPARTMENT OF ENERGY AGREEMENT NO. DE-\$G-03-88ER60913}




\section{PERFORMANCE REPORT}

This report is an amended version of the 1/91 final report. A total of 30 papers were published, relating to the funded work. The DOE rejected the renewal request for tool developments for genome analysis. DOE must be funding exceptionally prolific individuals!

The renewal ranked in the top $10 \%$ on review by the NIH genome project which is funding the continuation of my research.

\section{Publication funded in whole or in part by the DOE grant 1988-91}

30 papers. 24 papers are peer reviewed articles. 6 are reviews. These papers represent four funded positions for three years.

McClelland M., Hanish J., Nelson M. and Patel Y. (1988). KGB: A single type of buffer for all restriction endonucleases. Nucleic Acids Res. 16:364. McClelland M. (1988). Recognition sequences of Type II restriction systems are constrained by the $\mathrm{G}+\mathrm{C}$ content of host genomes. Nucleic Acids Res. 16: 2283-2294.

Hanish J. and McClelland M. (1988). Activity of restricticn endonucleases and methylases in potassium glutamate (KGB). Gene Anal. Tech. 5:105-107.

McCleliand $M$. and Nelson M. (1988). The 5'-GGATCC-3' cleavage specificity of BamHI is increased to $5^{\prime}$-CCGGATCCGG-3' by sequential double methylation with M.Hoall and M.BamHI. Gene 74: 169-176.

McClelland Mi. and Nelson M. (1988). The effect of site-specific methylation on restriction endonucleases and DNA modification methyltransferases. Gene 74: 291-304.

Weil M. and McClelland M. (1989). Enzymatic cleavage of a bacterial genome into two pieces at a ten-base-pair recognition site. Prec. Natl. Acad. Sci. U.S.A. 86: 51-55.

Fatel Y., Nelson M. and McClelland M. (1989). Methylation at overlapping E. coli. dam (Gm6ATC) sites does not block cleavage by the Nrul (TCGCGA) isoschizomers Amal, SalDI and Srel. Nucleic Acids Res. 17: 3613.

Nelson M. and McClelland M.(1939). Effect of site-specific methylation on DNA modification methyltransferases and restriction endonucleases. Nucleic Acids Res. 17: r388-r405.

Hanish J. and McClelland M. (1989). Controlled partial restriction digestions of DNA by competition with modification methyltransferases. Analytical Biochem. 179:357-360. 


\section{papers continued}

Patel Y., Van Cott E., Wilson G.G. and McClelland M. (1990). Cleavage at the twelve-base-pair sequence TCTAGATCTAGA using $M \cdot X$ bal (TCTAGm6A) and Dpnl. Nucleic Acids Bes. 18: 1603-1607.

Bo-gin Qiang, Michael McClelland, Saibal Poddar, Alvydas Spokauskas and Michael Nelson. (1990). The apparent specificity of Notl (5'-GCGGCCGC-3') is enhanced by M-EnuDll and M-Bepl methylases (5'mCGCG-3'): Cutting bacterial chromosomes into a few large pieces. Gene 88:101-105.

Hanish J. and McClellani M. (1990). Methylase-limited partial Notl cleavage for physical mapping of genomic DNA. Nucleic Acids Res. 18:3287-3291.

Sobral B.W.S., Honeycutt R.J., Atherly A.G., and McClelland M. (1990) Analysis of rice (Oryza sativa L.) genome using pulsed-field gel electrophoresis and rare-cutting restriction endonucleases. Plant MoL. Biol. Rep. 8:252-274.

Welsh J. and McClelland M. (1990). Fingerprinting genomes using PCR with arbitrary primers. Nucleic Acids Res. 18: 7213-7218.

Welsh J., Petersen C. and McClelland M. 1991. Polymorphisms generated by arbitrarily primed PCR in the mouse: Application to strain identification and genetic mapping. Nucleic Acids Bes. 19: 303-306.

Welsh J. and McClelland M. 1991. Genomic fingerprints produced by PCR with consensus tRNA gene primers. Nucleic Acids Res. 19: 861-866.

Hanish J. and McClelland M. 1991. Enzymatic Cleavage of a bacterial chromosome at a transposon-inserted rare site Nucleic Acids Res. 19: 829832.

McClelland M. (1991). Site-specific methylation. Chapter in Molecular Biology LabFax, Bios scientific publishers, pp126-138.

Nelson M. and McClelland M. 1991. Site-specific methylation: Effect on DNA modification methyltransferases and restriction endonucleases. Nucleic Acids Res. 19: r2045-2071.

Welsh J., and McClelland M. 1991. Applications of PCR-based genomic fingerprinting to genetic mapping, population biology and epidemiology. Published by Juan March Foundation, Madrid, Spain 263:65-68.

Hanish J., Rebelsky, MCClelland M. and Westbrook C. (1991). Methylase-limited partial Notl cleavage for physical mapping around the $a b /$ locus. Genomics 10:681-685.

Wong K.K. and MCClelland M.1991. PCR with $\mathrm{m}^{5} \mathrm{C}$ replacing dCTP. Nucleic Acids Res. 19. $1031-1085$.

Hanish J., Rebelsky, McClelland M. and Westbrook C. 1991. Application of Methylase-limited partial Notl cleavage for physical mapping of the abl locus. Genemics 10:681-685. 


\section{Papers continued}

Sobral, B.W.S., R.J. Honeycutt, A.G. Atherly and M. McClelland. 1991. Electrophoretic separation of the three Rhizobium meliloti replicons. \&. Bacteriol. 173:5173-5180.

Poddar S. and McClelland M. 1991. PFE characterization of the genomes of five species of Staphylococcus. DNA Cell Biol. 10:663-669.

Welsh J., McClelland M., Honeycutt R.J. and Sobral, B.W.S. 1991. Parentage determination in maize hybrids using arbitrarily primed PCR. Theoretical and Applied Genetics 82:473-476.

Welsh J., and McClelland M. 1991. Genomic fingerpinting with APPCR using pairwise combinations of primers: Application to genetic mapping of the mouse. Nucleic Acids Res. 19:5275-5279.

Sobral B.W.S. and McClelland M. 1991. DNA methylases as a tool to alter the specificity of restriction endonucleases. Chapter 12, vol. 6 Protocols in Mol. Biol. (in press). 


\section{Objectives}

The object of our current grant is to develop novel methods for mapping of the human genome. The techniques to be assessed were:

(i) three methods for the production of unique sequence clones from the region of interest;

(ii) novel methods for the production and separation of multi-megabase DNA fragments;

(iii) methods for the production of "physical linking clones" that contain rare restriction sites;

(iv) application of these methods and available resources to map the region of interest.

In the first two years of funding $\mathrm{I}$ and $\mathrm{Dr}$. Westbrook, my former co$\mathrm{PI}$ at the University of Chicago developed methods for physical mapping and the production of arrayed clones. This concentrated on our respective areas of expertise.

The half of the work in Dr. Westbrooks lab involved the assignment of clones to the long arm of chromosome 5 in accordance with aim (i). Since she is submitting a DOE grant 1 think it is fair to allow her to describe that half of the work.

We have also concentrated on developing rare-cleavage tools based or restriction endonucleases and methylases, as described in aim (ii). The following is a report performed over the last year for the McClelland half of the grant.

We studied the effect of methylation on enzymes used for PFE mapping of the human genome.

In a collaboration, we characterized two new isoschizomers of rare cutting endonucleases.

We developed a reliable way to produce partial digests of DNA in agarose plugs and applied it to the human genome.

We applied a method to double the apparent specificity of the "rarecutter" endonucleases.

Aim (iii) was not a success, except that controls we performed for experiments in this part were the basis of our renewal (see Preliminary Results in the Grant Application for details). 


\section{Effect of methylation}

The human genome is $A+T$ rich and $5^{\prime}-C^{-C G}-3^{\prime}$ is under-represented about five-fold compared to the frequency that would be expected if the bases were randomly distributed (Swartz et al., 1962; Bird, 1980). Most restriction endonuclease recognition sequences that occur infrequently in the human genome accordingly contain one or more 5'-CG-3' dinucleotides. Furthermore, most 5'-CG-3' dinucleotides in the human genome are methylated at 5'-m5 CG-3'.

DNA methylation in the human genome varies between cell types and restriction maps of human DNA may vary between cell types and chromosomal loci (Brockdorff et al., 1989; Lindsay and Bird, 1986). We showed that specific cytosine methylations at the C-5 position in vitro block cleavage by nineteen of twenty "rare cutting" endonucleases that we have tested. John Hanish, a graduate student and Mike Nelson, purified the methylases M.Fnu DII (m5CGCG), M.Bsp RI (GGm5CC), M.Hpall (Cm5CGG) and M. Hhal (Gm5CGC). Methyl groups were introduced into the recognition sequences of twenty restriction endonucleases that occur infrequently in the human genome: Aatll, Acclll, BmaDI BssHII, Cspl, Eagl, EcIXI, Kspl, Mlul, Mrol, Nael, Narl, Notl, Nrul, Pvul, Rsrll, Sacll, Sall, Sfil, Spll, and Spol. Nineteen of twenty endonucleases that we tested are sensitive to m5 C modification at one or more sites Table 1. These enzymes are therefore affected by human genomic methylation. Of interest later in this section, Notl is blocked by 5'-GCGGm5CCGC-3' or 5'-GCGGCM5CGC-3', and Sfil is blocked by $5^{\prime}-$ GGCm5CN 5 GGCC-3'.

Not listed in the table are 25 other experiments on the methylsensitivity of endonucleases that are not of major importance in human PFE mapping but are of interest in mapping other organisms.

Methyl-insensitive endonucleases

There are isoschizomers and many other restriction enzymes that have not yet been tested for methylation-sensitivity. Any $5^{\prime}-\mathrm{m}^{5} \mathrm{CG}-3^{\prime}$ insensitive isoschizomers that can be discovered should give reliable complete digests of human DNA regardless of methylation. Of all the endonucleases with $5^{\prime}-\mathrm{CG}-3^{\prime}$ in their recognition sequence that have been tested (Nelson and McClelland, 1989), only Acclll, Asull, Cfr9l, and Xmal are insensitive to $5^{\prime}-\mathrm{m}^{5} \mathrm{CG}-3^{\prime}$.

Rate effects independent of methylation

It was apparent that certain endonucleases preparations would not give complete digests. For example, complete digests were not easily obtained for Eagl, Pvul, Rsrll, Spll and Sacll. We were able to show that the respective isoschizomers EclXI, BmaDI, Cspl, Pspl and Kspl were more reliable. In some cases poor performance may be due to substantial 
differences in the rate at which endonucleases cleave, depending on flanking sequences.

A dramatic ( $>50$ fold) rate effect was also observed with one site for M.FnuDII methylase ( $\left.5^{\prime}-\mathrm{m}^{5} \mathrm{CGCG}-3^{\prime}\right)$. This is the first observation of a rate effect for a DNA methylase.

Methylation-limited partial digests.

Partial restriction enzyme digestion is necessary to map regions of genomic DNA when endonucleases cleave too frequently. The resulting large fragments are used to determine orientation and distance between adjacent probes (Smith and Birnsteil, 1976). They can also be used to determine distances from the end of a chromosome with a telomeric probe (Cross et al., 1989; Brown, 1989; Chen et al., 1989; de Lange, et al., 1990) or from a unique restriction site. Notl ( $5^{\prime} \ldots$...GC/GGCCGC...3') is a widely used restriction enzyme in genomic mapping. It cleaves infrequently due to its eight bp recognition site, and partial digestion of DNA yields fragments that are some of the largest produced for many genomes.

Partial cleavage of genomic DNA with Notl (and other endonucleases) is hindered by the agarose matrix in which large DNA must be embedded to prevent degradation. This matrix interferes with the restriction enzymes' accessibility to the DNA. Attempts at partial cleavage, by using less enzyme than required for complete digestion or limiting concentrations of $\mathrm{Mg}^{++}$(Albertsen et al., 1989), result in the outer DNA molecules being completely digested and interior DNA left intact. The proportion of the DNA molecules that are partially cleaved is small, creating a problem for investigators working at the limits of detection with hybridization protocols.

A methylase and restriction endonuclease, with the same site specificity, can be used in a competition reaction to overcome this problem (Hanish and McClelland, 1989). The enzymes are used in a specific ratio, in excess of that required to completely methylate or cleave the sample, resulting in a uniform partial digest as they penetrate the agarose matrix. The major obstacle to applying this technique to genomic DNA has been that most commercially prepared methylases are contaminated with co-purified, non-specific endonucleases that cleave DNA in the presence of $\mathrm{Mg}^{++}$. We have purified M.Bsp RI (5'...GGMCC...3') to a level sufficient for methylase-limited Notl partial cleavage. We demonstrated this method on E. coli and Salmonella genomic DNA (Hanish and McClelland, 1990). By changing the ratio of methylase to endonuclease, it is possible to choose the size of the partially cleaved fragments.

We are currently using methylase-limited Notl partials for the construction of a long-range physical map of the Salmonella genome. In brief, partial digesis are used to map distances of restriction sites from 
a unique M. Xbal/Dpnl (5'...TCTAGmA/TCTAGmA...3') (Patel et al., 1990; Weil and McClelland, 1989) cleavage site that has been inserted with a $\mathrm{Mu}$ transposon. We use probes for the transposon located on either side of the M.Xbal/Dpnl site. We are able to determine the distance of Notl sites up to $1 \mathrm{Mb}$ upstream from the M. Xbal/Dpnl unique cleavage site on this particular gel. By adjusting the amount of methylase used and pulse times of the gels, one can adjust the mapping range. Another advantage of this method is that it allows other endonucleases to cleave to completion in simultaneous reactions, while methods relying on interference with enzyme activity do not (Barlow and Lehrach, 1990).

It is our view that most DNA methylases could be purified to the level needed for these experiments. We are currently purifying M.FnuDII $\left(5^{\prime} \ldots\right.$...CGmCG...3') which competes with Nrul (5'...TCG/CGA...3') and M/ul $\left(5^{\prime} \ldots\right.$ A/CGCGT...3'). Preliminary results indicate that it can be made pure enough for methylase-limited partial digestion. High purity methylases have other potential uses for physical mapping. An example is the creation of a unique cleavage site by using a methylase to block all of its sites except for one that has been covered by a DNA-binding protein (Koob et al., 1988) or synthetic triple helix (Moser and Dervan,1987; Maher et al., 1989). Removal of the blocking agent allows subsequent cleavage with the corresponding restriction endonuclease.

Application to humans.

John Hanish has recently applied the methylation-limited partials of Notl to mapping a portion of the human genome. This method was able to extend the map around the $A b /$ locus (Hanish et al., manuscript submitted). In collaboration with Dr. Westbrook, we will also apply this to other regions, particularly in chromosome $5 q$, a region of interest to both of us. Cross-protection: the apparent specificity of endonucleases is doubled.

Bo-Qin Qiang, had previously characterized the restriction endonucleases Notl and Sfil, the only commercially available $G+C$ rich $8 b p$ restriction endonucleases. He and $i$ therefore, had a natural interest in extending their specificity.

The fact that "rare-cutting" restriction enzymes are blocked by DNA methylation at certain sites (Nelson and McClelland, 1989; Qiang et al., 1989) could be turned to practical advantage for mapping large genomes. A defined subset of restriction target sites can be blocked from cleavage at partly overlapping Methylase/endonuclease sites by prior methylation, a method referred to as "cross-protection" (Nelson et al., 1984). For example, the apparent specificity of the "rare-cutting" restriction endonuclease Notl should be enhanced almost two-fold by prior M.FnuDII methylation. Notl is blocked by methylation within its recognition 
sequence at 5'-GCGGCmCGC-3'. This sensitivity to methylation can be used to enhance the specificity of Notl in vivo and in vitro. Either M.FnuDll or M.Bepl methyltransferases (Methylase) (5'-mCGCG-3') will block Notl (5'GCGGCCGC-3') cleavage at overlapping Methylase/endonuclease sites 5'CGCG GCCGC-3' (equivalent to 5'-GCGGCCGCG -3'), and increase the apparent cleavage specificity of Notl about two-fold. This "crossprotection" procedure reduces the number of Notl fragments in the genomes of Escherichia coli and Bacillus subtilis, as resolved by Pulsed field electrophoresis. Application of this method to large DNAs in vitro requires the preparation of highly purified DNA Methylases.

The Notl restriction sites cleaved after M.FnuDll treatment are a subset of the unmodified Notl restriction sites. This subset relationship should help to identify those fragments that are adjacent to each other in Notl restriction maps. Furthermore, the M.FnuDIl/Notl fragments are, on average, about two-fold larger than Notl fragments, which should help in mapping larger regions than is possible using Notl digestion alone.

Application to human.

The human genome is $40 \% \mathrm{G}+\mathrm{C}$ and $5^{\prime}-\mathrm{CG}-3^{\prime}$ is the rarest dinucleotide in human DNA (Swartz et al., 1962; Bird, 1980). Endonucleases that are used to cut this genome into large pieces generally have recognition sequences that contain 5'-CG-3'. For instance, Notl sites (5'-GCGGCCGC-3') are among the rarest known restriction targets in the human genome. Furthermore, many Notl recognition sites in the genome are apparently blocked from cleavage (Lindsay and Bird, 1987), presumably, because of modification by the human $5^{\prime}-\mathrm{m}^{5} \mathrm{CG}-3^{\prime}$ specific Methylase at $5^{\prime}$ Gm5CGGCCGC-3' or 5'-GCGGCm5CG-3'. Such methylated sites cannot be cleaved by Notl (Nelson and McClelland, 1989). Unmethylated, cuttable, Notl sites occur once every $1,000,000 \mathrm{bp}$, on average, in partly modified human DNA.

Most unmodified Notl sites occur in short $\mathrm{G}+\mathrm{C}$-rich "islands" and are associated with genes (McClelland and Ivarie, 1982; Bird, 1986; Brown and Bird, 1987). Furthermore, the sites for other "rare-cutting" endonucleases used in himan "megabase" mapping are clustered in such regions. This clustering of restriction sites in $\mathrm{G}+\mathrm{C}$-rich islands is problematic when constructing long-range restriction maps (cf., Dauwerse et al., 1989). However, over half of Notl sites can be expected to overlap 5'-CGCG-3' sequences, which are relatively common in $\mathrm{G}+\mathrm{C}$-rich islands. In fact, 80 of the 129 Notl sites in sequenced human nuclear DNA (obtained from the Genbank database) overlap M.FnuDll sites. Blocking these Notl sites should allow some of these $\mathrm{G}+\mathrm{C}$-rich islands to be bridged.

Enhancement of other "rare-cutting" endonucleases.

For human chromosome mapping, several other selected Methylase/endonuclease combinations may be useful. A list of some of the 
more immediately practical possibilities reproduced from (Qiang et al., 1990) are listed in Table 2.

Cross-protection of a "rare-cutting" endonuclease creates a new cleavage specificity and doubles the average fragment size compared to that produced by the endonuclease alone. If the appropriate Methylases are made available at the required purity, this method should be very useful in facilitating the construction of physical maps for large genomes.

\section{PCR with 5-methyl-dCTP replacing dCTP}

When dCTP is replaced by methyl5-dCTP in the polymerase chain reaction some templates cannot be efficiently amplified by Taq polymerase or VentTM polymerase using standard cycling parameters. However, this phenomenon can be overcome by increasing the temperature of the denaturation steps to $1000 \mathrm{C}$, or by adding dITP to destabilize the $\mathrm{m} 5 \mathrm{dC}: \mathrm{dG}$ base pairs. Once the block to amplification of $\mathrm{m} 5 \mathrm{dC}$-substituted DNA was overcome, methylated DNA from the "superpolylinker" of the plasmid pSL1180 was used as a substrate to check the methyl-sensitivity of a variety of restriction endonucleases (Wong and McClelland, 1991). The m5dC-substituted DNAs should also be valuable substrates for defining the specificity of methyl-dependent endonucleases.

\section{New Restriction Endonucleases.}

The need to find methyl-insensitive restriction endonucleases led us to be interested in screening for new enzymes. There is a loose correlation between host $\mathrm{G}+\mathrm{C}$ content and the expected frequency of restriction endonucleases (McClelland 1988). This fact was used to select species to screen and $G+C$ rich viral DNAs were used as substrates. Mike Nelson purified three endonucleases that are of significance in human mapping. The first, Pspl (CGTACG), is the first practical isoschizomer of $S p / l$ for PFE. This recognition site is calculated to be the rarest of the six base specificities in the human genome because it has two occurrences of the rare dinucleotides $C G$ and one of the rare dinucleotide TA within its recognition sequence and $A+T$ rich sequences tend not to group with $G+C$ rich sequences. It will be commercially available soon. The second endonuclease Cspl is a superior isoschizomer of Rsrll (CGGWCCG). It has an effective 6.5 bp specificity and two CGs. Our application of this enzyme to PFE is published (Weil and McClelland, 1989). It is now available commercially. Finally, an isoschizomer of Nrul (TCGCGA), Spol with a superior yield was obtained and is now commercially available.

In collaboration with Boehringer Mannheim Biochemicals we have tested a new eigit base cutter, Swal. This enzyme has proven extremely useful in the mapping of $G+C$ rich DNAs (Sobral et al., submitted). In collaboration with Stratagene, we are currently assessing another new eight-base pair endonuclease. 
TABLE

High frequency cross-protections for megabase mapping

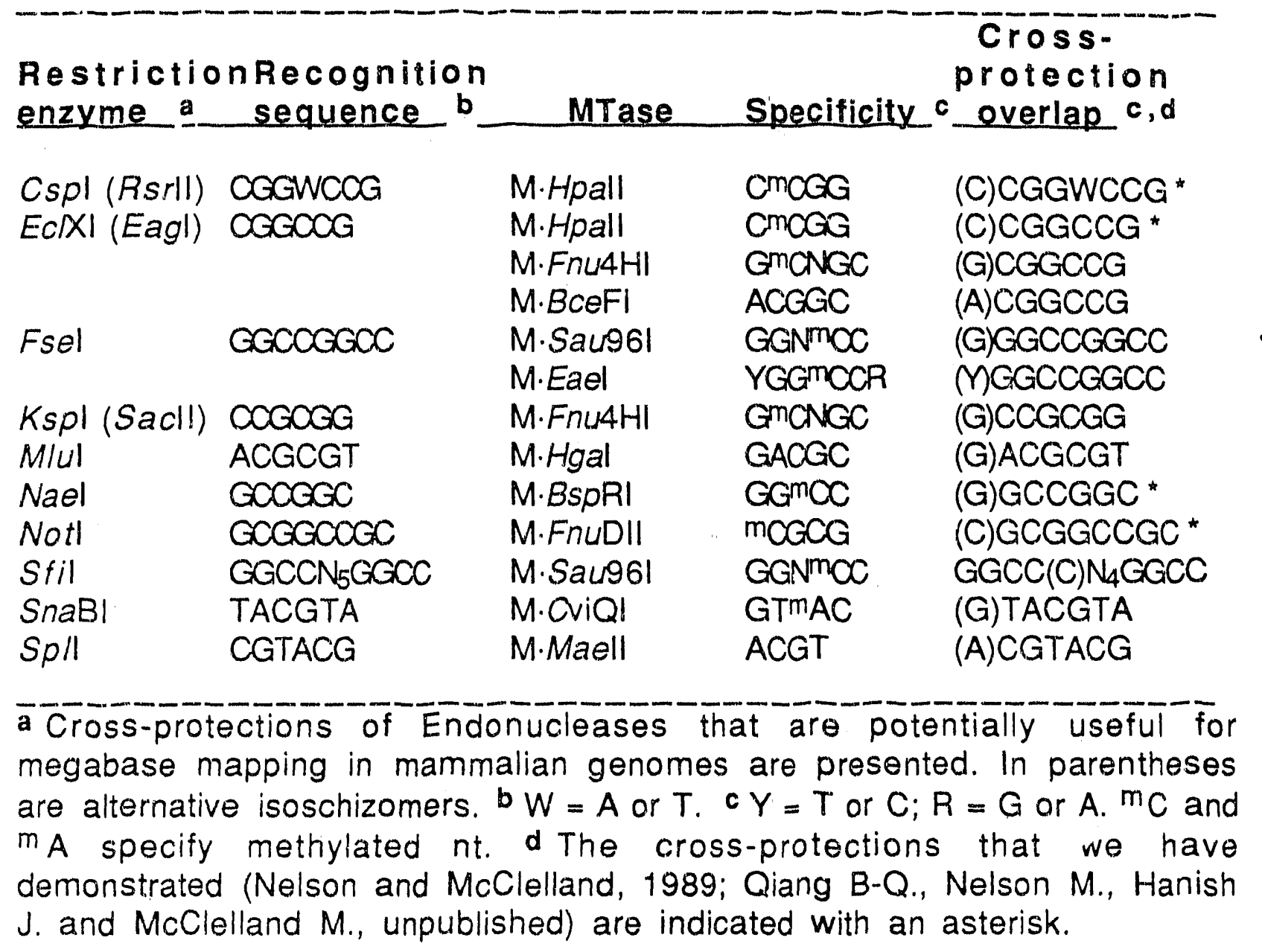




\section{Future directions}

Our work on methylases as tools for physical mapping has been very successful. It is our intention to continue with this work. We will apply for funding on methylases as tools in human genome mapping in a forthcoming application.

An off-shoot of our work on aim (iii) of our original proposal, which was for physical linking clones, has led us to a PCR fingerprinting method which is described in a proposal declined for renewal of this grant.

A brief review of these areas is given:

Genomic fingerprinting by Arbitrarily Primed PCR: Strair classification and genetic mapping.

Simple and reproducible fingerprints of complex genomes can be generated using single arbitrarily chosen primers and the polymerase chain reaction (PCR) (Welsh and McClelland, 1990). An arbitrarily primed (AP-PCR) fingerprint is generated by subjecting a small amount of template DNA to PCR at relaxed stringency with any randomly selected PCR primer (with a few minor restrictions). Divergence of even a fraction of a percent between two genomes often results in a different fingerprint pattern because a somewhat different set of sites in the genome have the best matches with the primer. PCR products that are shared between only some individuals act as polymorphic markers, equivalent to other polymorphic characters used in phylogenetic and genetic mapping methods. Each primer gives a different pattern of AP-PCR products, each with the potential of detecting polymorphisms between strains. Thus, the data produced allows the differentiation of even closely related strains of the same species.

The generality of the method is demonstrated by application to a variety of strains within twelve species of bacteria, three species of plant and two mammals, including humans. For example, the patterns produced by two different primers distinguish seven commonly used mouse ( $M$. domesticus) inbred lines (Welsh, Peterson and McClelland, 1991). This demonstrates the utility of the technique in sirain identification. Similarly, the same primers result in AP-PCR patterns that show four polymorphisms in five strains of $S$. pyogenes (serotype A). With a series of primers we have built a phylogenetic tree that shows the evolutionary relationships between these bacterial strains.

One can take advantage of the heritable characteristics of the polymorphic bands produced by AP-PCR fingerprinting. Using fingerprinting of DNA from mouse recombinant inbreds we have been able to determine map positions of such polymorphisms very quickly. For example, a primer that gave a pattern that distinguished $\mathrm{C} 57 \mathrm{BL} / 6 \mathrm{~J}$ from DBA/2J was applied to a series of recombinant inbreds derived from these strains. The pattern of inheritance can be compared to the pattern of 
inheritance for other markers that have already been mapjed in this set of recombinant inbreds. We are able to identify up to six polymorphisms per lane in polyacrylamide gels. PCR generated DNA polymorphisms can be isolated directly from gels and reamplified to use as probes in genome walking or restriction mapping strategies. No cloning is necessary. Of ten primers we have used so far, those that produce the most polymorphisms (three to six per gel) have stretches of simple repeats. AP-PCR genetic mapping strategy makes it feasible to put many thousands of DNA markers on the mouse genetic map. We have also begun to generate fingerprints with PCR using consensus primers for interspersed repetitive sequences (IRS) that may have associated variable number tandem repeat polymorphisms.

AP.FCP. fingerprinting is, in many respects, dramatically easier and faster than established methods for strain classification or genetic mapping and most of the steps in AP.PCR are automatable.

PCR using tRNA consensus primers produces fingerprints characteristic of genomes.

There are a large number of tRNA genes dispersed throughout the gennmes of most organisms. The shared sequence motis of tRNA genes implies that primers for the polymerase chain reaction that contain consensus tRNA sequences are likely to result in a number of characteristic PCR products. Experience with fingerprinting of genomas using PCR with arbitrary primers (AP-PCR) and Alu-PCR of the human genome, indicates that complex fingerprints can be quite reproducible. tDNA-PCR, so called to indicate that DNA encoding tRNAs is the target for amplification, is likely to give fingerprints that vary at the species or genus level as the tRNA gene clusters evolve. Thus, the fingerprints would be a measure of DNA relatedriess at this level of classification. This is in contrast to AP-PCR, which is very sensitive to DNA sequence changes and which is an excellent way to detect intra-specific polymorphisms.

Consensus primers were developed using tRNA sequences, of which over 500 are known. Given the variability in tRNA gene sequences jetween isoacceptors from different species, and the even greater difference between tRNAs for different amino acids, a substantial universal consensus does not exist. However, a reasonable match with a fraction of all tRNAs can be devised.

The polymerase chain reaction using only a single "consensus" tRNA gene primer, or a pair of primers oriented to produce diverging products, amplifies a set of DNA tragments in bacterial, plant and animal genomic DNAs. These PCR fingerprints are presumably derived from the regions between closely linked tRNA genes. The pattern of the PCR products is determined by which genomes and which primer(s) are used. 
A survey was performed on forty strains of bacteria, representing many strains from five species of Staphylococcus, four species of Streptococcus and a species of Enterococcus. (Welsh and McClellan, 1991). The organization of the tRNA genes in these species has not been described, but they are presumably similar to those of other related bacteria, such as Bacillus. tDNA-PCR fingerprints are largely conserved within a species and, in bacteria, most products in the fingerprint are conserved between closely related species.

tDNA-PCR should work on a wide variety of species, because tRNA genes are hiçhly conserved, are abundant and are generally arranged in clusters. Fingerprints generated for the maize, rice and human genomes with at least one of the two pairs of primers we tested.

Organisms one essentiaily knows nothing about can immediately be examined for relatedness. The method presented represents the simplest available universal way to reliably compare genomes of organisns at the species/genus level. This method should be applicable to epidemiology, phylogeny ar,d population genetics for most, if not all, species.

We have now developed a diagnostic test based on these ideas (Welsh and McClelland, in press; McClelland et al., in press). 
Associated publications by former co-PI

Le Beau M.M., Chandrasekharappa S.C., Lemons R.S., Schwartz J.L., Larson R.A., Aral N. and Westbrook C.A. Molecular and cytogenetic analysis of chromosome 5 abnormalities in myeloid disorders: chromosomal localization and physical mapping of IL-4 and IL-5. Cancer Cells 7 53-56 (1989)

Chandrasekharappa S.C., Rebelsky M.S., Firak R.A. Le Bisau M.M. and Westbrook C.A. A long range restriction map of the interleukin 4 and interleukin 5 linkage group on chromosome 5 . Genomics (in press)

Hooberman-A-L. Rubin-C-M. Barton-K-P. Westbrook-C.A.Detection of the Philadelphia chromosome in acute lymphoblastic leukemia by pulsed-field gel electrophoresis. Blood. 1989 Aug 15. 74(3). P 11017 .

Hooberman-A-L. Carrino-J-J. Leibowitz-D. Rowley-J-D. Le-Beau-M-M.Arlin-Z-A. Westbrook-CA. Unexpected heterogeneity of BCR-ABL fusion mRNA detected hy polymerase chain reaction in Philadelphia chromosome-positive acute lymphoblastic leukemia. Proc-Natl-Acad-Sci-U-S-A. 1989 Jun. 86(11). P 4259-63.

Rubin-C-M. Blazar-B-R. Hooberman-A-L. Dickler-M-N. Miller-B-A. Westbrook-C-A. A deletion/insertion polymorphistr in the hurnan BCR gene on chromosome 22. Nucleic-Acids-Res. 1988 Sep 12. 16(17). P 8741.

Rubin-C.M. Carrino-J-J. Dickler-M-N. Leibowitz-D. Smith-S-D. Westbrook-C-A. Heterogeneity of genomic fusion of $B C R$ and $A P, L$ in Philadelphia chromosome-positive acute lymphoblastic leukemia. Proc-Natl-Acad-Sci-U-S-A. 1988 Apr. 85(8). P 2795-9.

Kwiatkowski-D.J. Westbrook-C-A. Bruns-G-A. Morton-C-C. Localization of gelsolin proximal to ABL on chromosome 9. Am-J.Hum-Genet. 1988 Apr. 42(4). P 565-72.

Moormeier-J-A. Ratain-M-J. We:tbrook-C-A. Vardiman-J-W. Daly-K-M. Golomb-H-M. Low-dose interferon alfa-2b in the treatment of hairy cell leukemia. J-Natl-Cancer-Inst. 1989 Aug 2. 81(15). P $1172 \cdot 4$,

Ratain-M-J. Golomb-H-M. Vardiman-J-W. Westbrook-C-A. Barker-C. Hooberman-A. Bitter-M-A. Daly$K$. Relapse after interferon alfa-2b therapy for hairy-cell leukemia: analysis of prognostic variables. J-Clin-Oncol. 1988 Nov. 6(11). P 1714-21.

Westbrook-C-A.The ABL oncogene in human leukemias. Blood-Rev. 1988 Mar. 2(1). P 1-8. (Review).

Westbrook-C-A. Rubin-C-M. Carrino-J-J. Le-Beau-M-M. Bernards-A. Rowley-J-D. Long-range mapping of the Philadelphia chromosome by pulsed-field gel electrophoresis. Blood. 1988 Mar. 71/3). P 697-702. 


\section{REFERENCES}

Albertsen, H., M., LePaslier, D., Abderrahim, H., Dausset, J., Cann, H. and Cohen, D. (1989) Nucleic Acids Res. 17, 808.

Ausubel, F. M., Brent, R., Kingston, R. E., Moore, D. D., Seidman, J. G., Smith, J. A. and Struhl, K. (1989) Current Protocols in Molecular Biology, Section 2.9.

Barlow, D. P. and Lehrach, H. (1990) Nucleic Acids Res. (in press).

Bird A.P. (1980) DNA methylation and the frequency of CpG in animal DNA. Nucleic Acids Res. 8 : $1499-1504$.

Bird A.P. (1986) CpG-rich islands and the function of DNA methylation. Nature 321: 209. 213.

Brown W.R. and Bird A.P. (1986) Long-range restriction site mapping of mammalian genomic DNA. Nature 322:477-481.

Brown, W. R. A. (1989) Nature 338, 774-776.

Cheng, J. F., Smith, C. L. and Cantor, C. R. (1989) Nucleic Acids Res. 17, 6109-6127.

Cross, S. H., Allshire, R. C., Mckay, S. J., McGill, N. I. and Cooke, H. J. (1989) Nature 338 ,

$771-774$.

Dauwerse H.G., Van Ommen G.J., Breuning M.H., and Pearson P.L. (1989)Cosmid vector pCpG and plasmid vector pKNUN1, and their use for cloning DNA sequences adjacent to sites for rare cutting restriction endonucleases. Nucleic Acids Res. 17: 3603.

de Lange, T., Shiue, L., Myers, R. M., Cox, D. R., Naylor, S. L., Killery, A. M. and Varmus, H. E. (1990) Mol. Cell. Biol. 10, 518-527.

Gardiner, K., Laas, W. and Patterson, D. (1986) Somatic Cell Mol. Genet. 12, 185-195.

Hanish J. and McClelland M. (1988) Activity of restriction endonucleases and methylases in potassium glutamate (KGB). Gene Anal. Tech. 5:105-107.

Hanish, J. and McClelland, M. (1989) Anal. Biochem. 179, 357-360.

Koob, M., Grimes, E. and Szybalski, W. (1988) Science 241, 1084-1086.

Kuppur D., Jian-Guang Z., Kiss A. and Venetianer P. (1988) Cloning and structure of the M.Bepl modification methyltransferase. Gene 74: 33.

Lindsay S. and Bird A.P. (1987) Use of restriction enzymes to detect potential gene sequences in mammalian DNA. Nature. 327: 336-8.

Lunnen K.D., Barsomian J.M., Camp R.R., Card C.O., Chen S-Z., Croft R., Looney M.C., Meda M.M., Moran L.S., Nwankwo D.O., Slatko B.E., Van Cott E.M. and Wilson G.G. (1988) Cloning type-1l restriction-modification genes. Gene 74 :25-32.

Maher, L. J., Wold, B. and Dervan, P. B. (1989) Science 245, 725-730.

McClelland $M$. and Ivarie R. (1982) Asymmetrical distribution of CpG in an "average" mammalian gene. Nucleic Acids Res. 10: 7865-7877.

McCleliand M., Jones R., Patel Y., and Nelson M. (1987) Restriction endonucleases for pulsed field mapping of bacterial genomes. Nucleic Acids Res. 15:5985-6005.

Moser, H. E. and Dervan, P. B. (1987) Science 238, 645-650.

Nelson M. and McClelland M. (1987) Purification and assay of type II DNA modification methylases. Methods in Enzymology. $155: 32-35$.

Nelson M. and McClelland M. (1989) Effect of site-specific methylation on DNA modification methyltransferases and restriction endonucleases. Nucleic Acids Res. 17:389-415.

Nelson M., Christ C. and Schildkraut I. (1984) Alteration of apparent restriction endonuclease recognition specificities by DNA methylases. Nucleic Acids Res. 12: 5165-5173.

Posfai, G., Kiss, A., Erdei, S., Posfai, J. and Venetianer, P. (1983) J. Mol. Biol. 170, 597. 610.

Ratet, P. and Richaud, F. (1986) Gene 42, 185-192.

Schwartz, D. C. and Cantor, C. (1984) Separation of yeast chromosome-sized DNAs by pulsed field gradient gel electrophoresis. Cell $37: 67-75$.

Smith, H. O. and Birnsteil, M. L. (1976) Nucleic Acids Res. 3, 2387-2398.

Smith C.L., Econome J.G., Schutt A., KIco S. and Cantor C.R. (1987) A physical map of the Escherichia coli K-12 genome. Science 236:1448-53. 
Storts, D. A. and Markovitz, A. (1988) J. Bact. 170, 1541-1547.

Swartz M.N., Trautner T.A. and Kornberg A. (1962) Enzymatic synthesis of DNA. 11. Further studies on nearest neighbor base sequences in DNA's. J. Biol. Chem. $237: 1961-1967$.

Szomolanyi, E., Kiss, A. and Venetianer, P. (1980) Gene 10, 219-225.

V'eil M. and Micclelland M.: Enzymatic cleavage of a bacterial genome into two pieces at a tenbase pair recognition site. Proc. Natl. Acad. Sci. U.S.A. 86 (1989) 51-55.

Xia, Y. and Van Etten, J. L. (1986) A.jl. Cell. Biol. 6, 1440-1445. 


